\title{
Growth curve of female collared peccaries (Pecari tajacu) raised in captivity in the Brazilian Amazon Region
}

\author{
[Curva de crescimento de fêmeas cateto (Pecari tajacu) criados em cativeiro \\ na Amazônia Brasileira] \\ A.D.V. Garnero ${ }^{1}$, C.R. Marcondes ${ }^{2}$, N.I. Albuquerque ${ }^{3}$, R.O. Araújo ${ }^{4}$, \\ Y. Pendu ${ }^{5}$, D.A. Guimarães ${ }^{6}$ \\ ${ }^{1}$ Universidade Federal do Pampa - São Gabriel, RS \\ ${ }^{2}$ Embrapa Pecuária Sudeste - São Carlos, SP \\ ${ }^{3}$ Embrapa Amazônia Oriental - Belém, PA \\ ${ }^{4}$ Programa de pós-graduação - FAV-UnB - Brasília, DF \\ ${ }^{5}$ Universidade Estadual de Santa Cruz - Santa Cruz, BA \\ ${ }^{6}$ Universidade Federal do Pará - Belém, PA
}

\begin{abstract}
This work aims to determine the most suitable nonlinear model to describe the growth of female collared peccaries (Pecari tajacu). The monthly records of the weight of 10 captive female collared peccaries over a period of two years in the Brazilian Amazon Region were used. The growth models used were the Von Bertalanffy, Brody, Gompertz and Logistic. The parameters were estimated by using the NLIN procedure from the SAS application. The criteria used to verify the adjustment of the models were: asymptotic standard deviation (ASD); coefficient of determination $\left(\mathrm{R}^{2}\right)$; average absolute residual deviation (ARD) and the asymptotic rate (AR). The Brody model and the Logistic model estimated the highest (19.44kg) and the lowest $(19.18 \mathrm{~kg})$ asymptotic weight $(A)$, indicating the lowest $(0.0070 \mathrm{~kg} / \mathrm{day})$ and the highest $(0.0121 \mathrm{~kg} / \mathrm{day})$ maturation rate $(K)$. These results and the coefficients of phenotypic correlation that varied from -0.75 and -0.47 confirmed the antagonistic nature between these parameters. The Brody model estimated the lower value for ARD, a limiting factor for describing the lowest value for AR through this model. The Brody model showed the best adjustment for AR, although the other models also showed a suitable adjustment to the weight data of said species/gender. Based on the AR obtained in this work, the Brody model is recommended for adjusting the growth curve of the female collared peccaries. Depending on the estimated values, especially for $K$, this trait can be included in a selection index.
\end{abstract}

Keywords: nonlinear models, asymptotic weight, growth rate

\section{RESUMO}

Com o objetivo de ajustar modelos não-lineares, foram utilizados registros mensais do peso de 10 fêmeas de cateto (Pecari tajacu) coletados durante dois anos, no criatório do campo experimental Álvaro Adolfo da Embrapa Amazônia Oriental, Belém, PA. Utilizaram-se os modelos de Von Bertalanffy, Brody, Gompertz e Logístico. Os parâmetros foram estimados usando o procedimento NLIN do aplicativo SAS. Os critérios utilizados para verificar o ajuste dos modelos foram: desvio padrão assintótico (ASD); coeficiente de determinação $\left(R^{2}\right)$; desvio médio absoluto dos resíduos (ARD) e o índice assintótico $(A R)$. Os modelos Brody e Logístico estimaram, respectivamente, o maior $(19,44 \mathrm{~kg})$ e o menor $(19,18 \mathrm{~kg})$ peso assintótico (A), caracterizando a menor $(0,0064 \mathrm{~kg} /$ dia) e a maior $(0,0113 \mathrm{~kg} /$ dia $)$ taxa de maturação $(\mathrm{K})$, haja vista a natureza antagônica entre estes parâmetros, comprovada pela correlação fenotípica variando entre -0,75 à -0,47. O modelo Brody estimou o menor valor para o ARD, fator limitante para caracterizar o menor valor para o AR por este modelo. Considerando o AR, o modelo Brody apresentou o melhor ajuste, contudo, pelos valores encontrados, os demais modelos também apresentaram ajuste adequando aos dados ponderais da referida espécie/sexo. Com base no AR adotado neste trabalho,

Recebido em 1 de março de 2012

Aceito em 13 de março de 2013

E-mail: analiagarnero@yahoo.com.br 
recomenda-se o modelo Brody para ajustar a curva de crescimento de fêmeas de cateto (Pecari tajacu). Em razão dos valores estimados, sobretudo, para a $K$, essa característica pode ser incluída em um índice de seleção. Contudo, estudos com grupos mais representativos e criados em outras condições se faz oportuno.

Palavras-chave: modelos não-lineares, peso assintótico, taxa de crescimento

\section{INTRODUCTION}

The importance of preserving zoogenetic resources appears in current global discussions on sustainability since wild fauna is important both for human food safety and ecosystem balance. The sustainable use of these resources is a must, i.e., local socioeconomic development and permanence of the biodiversity must be ensured at the same time.

Wild fauna can become a significant source of development for the Brazilian Amazon Region if it is managed in a sustainable manner, because it will contribute to food safety and utilization of byproducts such as fat, skin, hair etc. The political project for the socio-environmental development of the Brazilian Amazon Region provides for initiatives that are founded on this philosophy and can offer medium and long-term alternative methods for the sustainable use of natural resources.

The exploitation of wild fauna is part of the Amazon Region economy, because in countries such as Colombia, Peru and Venezuela this activity provides high financial value (Mayor et al., 2007). Subsistence hunting represents a great part of the protein portion of food for rural families in the Amazon Region (Robinson and Bodmer, 1999; Bodmer, 2000; Fuccio et al., 2003). Animals such as the paca Cuniculus paca, the agouti Dasyprocta sp., the capybara Hydrochoerus hydrochaeris, the armadillo Dasypus sp., the collared peccary Pecari tajacu, the white-lipped peccary Tayassu pecari and the brocket deer Mazama sp. are much used in subsistence hunting in rural areas of the Brazilian Amazon Region (Bonaudo et al., 2005).

The collared peccary is a native wild species much sought after for subsistence consumption and commercial hunting, especially in the rural region of many Latin American countries (Mayor et al., 2007). Collared peccary breeding in captivity is allowed by the Brazilian legislation, which has been encouraging the installation of wild animal breeding facilities since the hunting ban in force in the national territory since 1967.

Breeding of wild fauna in ex situ conditions plays an essential role not only in animal production but also in preservation, since it allows for the conservation of the genetic diversity of populations under management. Nevertheless, studies on the feasibility of raising different species of wild animals in captive breeding systems are still unusual.

Breeding the collared peccary in captivity can contribute to the sustainable development of the Amazon Region because this activity can be a source of income diversification for rural commercial farmers, in addition to contributing to food supply in communities that are located far from large urban centers. Nonetheless, more studies on the biology of this species are required in order to understand the production chain and production costs in order to make the marketing of this new kind of product feasible.

Freitas (2005) points out that the analysis of repeated measurements is important in animal production because it includes situations in which experimental units or individuals of different subpopulations or treatments (gender and race among others) are analyzed under several conditions (time, doses, etc.). According to the same author, the growth curves in animal production which relate the weight $(y)$ and the age ( $\mathrm{t}$ ) of the animals, by means of nonlinear models, stand out.

Directed at the sustainability of the production of wild animals in captivity for slaughtering and marketing, the aim of this work was to adjust Von Bertalanffy, Brody, Gompertz and Logistic nonlinear models to the growth data for female collared peccaries raised in captivity in the Amazon Region. 


\section{MATERIAL AND METHODS}

The data corresponds to a group of 10 female collared peccaries born in 2001 and 2002. The record pairs of weight-age were obtained through monthly weighing that took place from the time when the animals were 260 days of age (first weighing) to when they were 750 days of age (last weighing), totaling 19 weight/age records per animal and 190 observations for the entire data group. These females were bred at the Unidade de Pesquisa Animal (Animal Research Unit) Senador Álvaro Adolpho in the Embrapa Amazônia Oriental, Belém, Pará, Brazil.

The animals were kept in $36 \mathrm{~m}^{2}$ cages in family groups made up of the brood, the young, adults, males and females. The family groups were given $(500 \mathrm{~g} / \mathrm{animal})$ swine growth and fattening feed (14\% RP - raw protein) daily, in addition to a fodder supplement (Pennisetum hybridum) and regional fruits in season.

The Asymptotic Weight $(A)$ that corresponds to the animal weight at maturity and the Maturity Rate $(K)$ that corresponds to the speed in which the animal attains its adult weight were estimated. These parameters were predicted using four nonlinear mathematical models: Von Bertalanffy (Von Bertalanffy, 1957) $Y_{t}=A(1-$ $\left.B e^{-K t}\right)^{3}+\varepsilon ; \operatorname{Brody}\left(\right.$ Brody, 1945) $Y_{t}=A\left(1-B e^{-K t}\right)$ $+\varepsilon$; Gompertz (Laird, 1966) $Y_{t}=A e^{-B e^{\wedge}(-K t)}+\varepsilon$ and Logistic (Nelder, 1961), $Y t=A\left(1+e^{-K t}\right)^{-M}+$ $\varepsilon$, where: $Y$ represents the animal's weight at a certain age $(t) ; B$ represents the constant of integration which is related to the initial weight (animal's degree of maturity at birth); $M$ is the parameter that gives the curve its form; $e$ is the logarithm in natural base; $\varepsilon$ represents the random error associated with each weighting.

The model parameters were estimated by the Gauss-Newton algorithm by means of the NLIN procedure of the Statistical Analysis System software package, version 9.1 (Statistical..., 2003).

The criteria used for selecting the model for the best adjustment of the growth curve were: asymptotic standard deviation (ASD); graphical analysis of observed and estimated curves; coefficient of determination $\left(\mathrm{R}^{2}\right)$ and the average absolute residual deviation (ARD), statistics proposed by Sarmento et al. (2006), calculated as follows:

$$
\mathrm{ARD}=\frac{\sum_{\mathrm{i}=\mathrm{n}}^{\mathrm{n}}|\mathrm{Yi}-\hat{\mathrm{Y}} \mathrm{i}|}{\mathrm{n}}
$$

where $\mathrm{Yi}$ is the measured value of the animal's weight; $\hat{Y} i$ is the estimated value for the same weight and $n$ is the size of the sample. The lower the value of ARD, the better the adjustment of the growth curve.

In order to choose the best model, an asymptotic rate (AR) was created, as described by Ratkowsky (1990), which combined the criteria of ASD, ARD and $\mathrm{R}^{2},\left(\mathrm{AR}=\mathrm{ARD}+\mathrm{ASD}-\mathrm{R}^{2}\right)$. The maximum value $(100 \%)$ was attributed to the highest estimate of each criterion and the others were weighted against it. The lower the value of $A R$, the better the adjustment of the model.

In addition, the results generated for parameters $A$ and $K$ in each model were analyzed by orthogonal contrasts considering $5 \%$ significance by the Tukey test through all possible combinations of the adopted models.

\section{RESULTS AND DISCUSSION}

The Brody model was the function that estimated the highest asymptotic weight $A(19.44 \mathrm{~kg})$, whereas the lowest value was obtained by the Logistic model (19.18kg) (Table 1). A similar result was reported for Murrah breed buffaloes (Malhado et al., 2008) and for bovines (Garnero et al., 2005; Santoro et al., 2005).

The values of asymptotic weight estimated by the different models were not significantly different (Table 2). On the other hand, the Brody and Logistic models estimated, respectively, the lowest and the highest growth rate $K$ $(0.0070 \mathrm{~kg} / \mathrm{day} v s .0 .0121 \mathrm{~kg} / \mathrm{day})$ with significant differences $(\mathrm{P}<0.01)$ by the test of contrasts (Table 2). This result confirms the antagonism that exists between these parameters, since the higher the value of $K$, the faster the animal nears its asymptotic weight, i.e., the higher the speed of its growth (Garnero et al., 2005). This opposition can also be demonstrated through the phenotypic correlation coefficients, in which the amplitude of this association varied from -0.75 to -0.47 . 


\section{Garnero et al.}

Table 1. Parameter estimates (A, B, K and M) with their respective standard error (SE), and the criteria adopted to assess the model adjustment

\begin{tabular}{|c|c|c|c|c|c|c|c|c|}
\hline \multirow[b]{2}{*}{ Model } & \multicolumn{4}{|c|}{ Parameters Estimates \pm SE } & \multirow[b]{2}{*}{ ASD } & \multirow[b]{2}{*}{$\mathrm{R}^{2}$} & \multirow[b]{2}{*}{ ARD } & \multirow[b]{2}{*}{$\mathrm{AR}$} \\
\hline & $\begin{array}{c}A \\
(\mathrm{~kg}) \\
\end{array}$ & $B$ & $\begin{array}{c}K \\
(\mathrm{~kg} / \mathrm{dia}) \\
\end{array}$ & $M$ & & & & \\
\hline $\begin{array}{l}\text { Von } \\
\text { Bertalanffy }\end{array}$ & $19.29 \pm 0.28 \mathrm{a}$ & $0.6739 \pm 0.086$ & $0.0086 \pm 0.0008 \mathrm{ab}$ & - & 99.7 & 100 & 98.30 & 98.0 \\
\hline Brody & $19.44 \pm 0.33 \mathrm{a}$ & $0.9787 \pm 0.031$ & $0.0064 \pm 0.0006 \mathrm{a}$ & - & 100 & 100 & 87.74 & 87.7 \\
\hline Gompertz & $19.23 \pm 0.27 \mathrm{a}$ & $3.2182 \pm 0.681$ & $0.0101 \pm 0.0009 \mathrm{ab}$ & - & 99.6 & 100 & 99.35 & 98.9 \\
\hline Logistic & $19.18 \pm 0.25 \mathrm{a}$ & - & $0.0113 \pm 0.0009 b$ & $4.524 \pm 0.923$ & 99.7 & 100 & 100 & 99.7 \\
\hline
\end{tabular}

ASD = Asymptotic Standard Deviation; $\mathrm{R}^{2}=$ Coefficient of Determination in \%; ARD = Average Absolute Deviation in $\%$ and $\mathrm{AR}=$ Asymptotic Rate.

Averages followed by the same letter in the column do not present Minimum Significant Difference (MSD) in the orthogonal contrasts test.

Table 2. Analysis of orthogonal contrasts for the asymptotic weight and for the maturity rate among the models (degree of freedom 1 for all comparisons)

\begin{tabular}{lcccc}
\hline \multicolumn{1}{c}{ Contrasts between the models } & D.F & $\begin{array}{c}\text { Variance of } \\
\text { Contrast }\end{array}$ & F Value & P \\
\hline Asymptotic Weight & 1 & 0,00008 & 6,97 & $0,001^{*}$ \\
\hline Brody $v s$ Gompertz & 1 & 0,00012 & 11,17 & $0,002^{*}$ \\
Brody $v s$ Logistic & 1 & 0,00011 & 9,74 & $0,003^{*}$ \\
Brody $v s$ all & 1 & 0,00010 & 9,31 & $0,004^{*}$ \\
Brody + Bertalanffy $v s$ Gompertz + Logistic & 1 & .
\end{tabular}

*Significant Differences at $\mathrm{P}<0.01$; Value of $\mathrm{F}=$ Value calculated by the program in order to test the contrast significance.

The values of the determination coefficients $\mathrm{R}^{2}$ were maximum for all models used in the work (Table 1). At the same time, small variations of ASD were found $(0.04 \%)$, where the Brody model showed the largest variation and the Gompertz model, the smallest one. Nevertheless, these are small magnitude variations, which make any initial conclusion about the best adjustment model impossible.

On the other hand, the largest value of the average absolute residual deviation - ARD was estimated for the Logistic model while smaller deviations where obtained for the Brody model, followed by the Von Bertalanffy and Gompertz models (Table 1).

All the models (Figure 1) overestimated the weight between 244 and 447 days of age. The largest overestimation, obtained by the Brody model, varied between $0.23 \mathrm{~kg}$ and $1.34 \mathrm{~kg}$, for the beginning and the end of this interval, respectively. In the interval between 510 and 750 days of age, all the models underestimated the weights observed, and the largest underestimation was of $1.06 \mathrm{~kg}$ (Logistic model Figure 1) at 600 days of age and the smallest underestimation was of $0.06 \mathrm{~kg}$ (Von Bertalanffy model - Figure 1) at 540 days of age.
The analysis of the mean weights observed and predicted by the nonlinear models (Figure 1) indicates the inflection point of the curve, at around 300 days of age. Form this moment on, a slower growth of the animals can be observed and the growth becomes stable when they reach $19 \mathrm{~kg}$, which is the asymptotic weight $(A)$. Dubost et al. (2003) obtained a similar result when they studied the weight development of collared peccaries born in the French Guiana. Santos et al. (2004) reported that collared peccaries would be ready for slaughter when they reached $18 \mathrm{~kg}$.

Great amplitude was observed in the values for parameter $A$, which indicates that there are animals with an adult weight disparity of approximately $5 \mathrm{~kg}$. This result indicates a difference in the growth rate that can be as high as 100 days between the most precocious and the latest animal to attain asymptotic weight (Figure 2 ). This observation confirms the vast genetic variability seen in the Tayassuidae, and strengthens the idea that some wild animals if well managed in captivity can become an important source of income and research. 

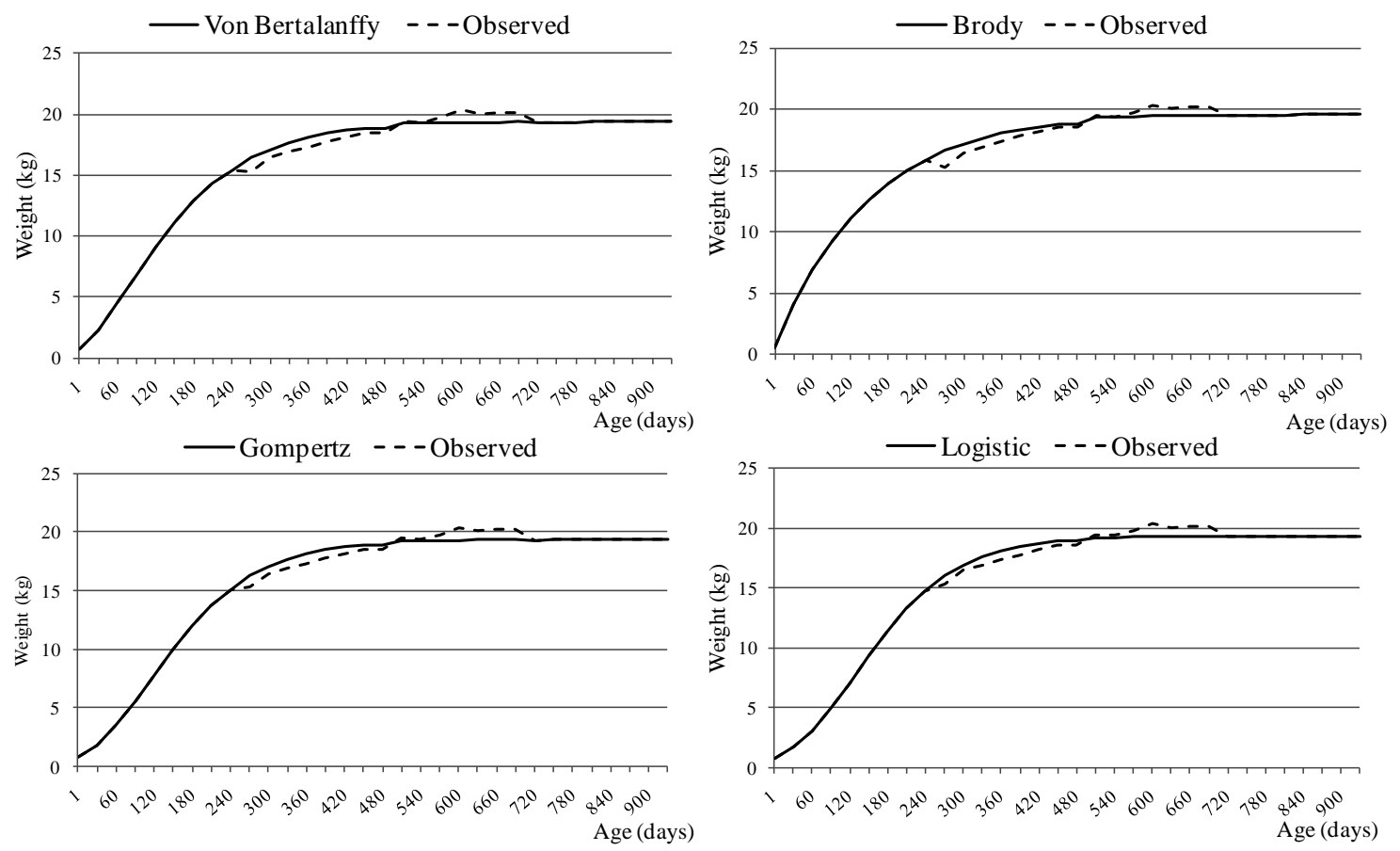

Figure 1. Growth curve obtained by the avarage of weight observed and by weight stated by Von Bertalanffy, Brody, Gompertz and Logistic models at diferent ages.

Parameter $K$ represents the maturity rate and indicates the growth speed for attaining the asymptotic weight from its initial weight. The higher the value of $K$, the faster the animal nears its asymptotic weight, i.e., the higher its growth speed (Garnero et al., 2005). Animals with a high $K$ value show precocious maturity when compared to individuals with a lower $K$ value and a similar initial weight (Figure 2), representing accurately the relative growth speed of the animals. An animal with high growth rate (Figure 2) takes approximately 200 days to attain the slaughter weight whereas an animal with a low growth rate needs an additional 100 days.

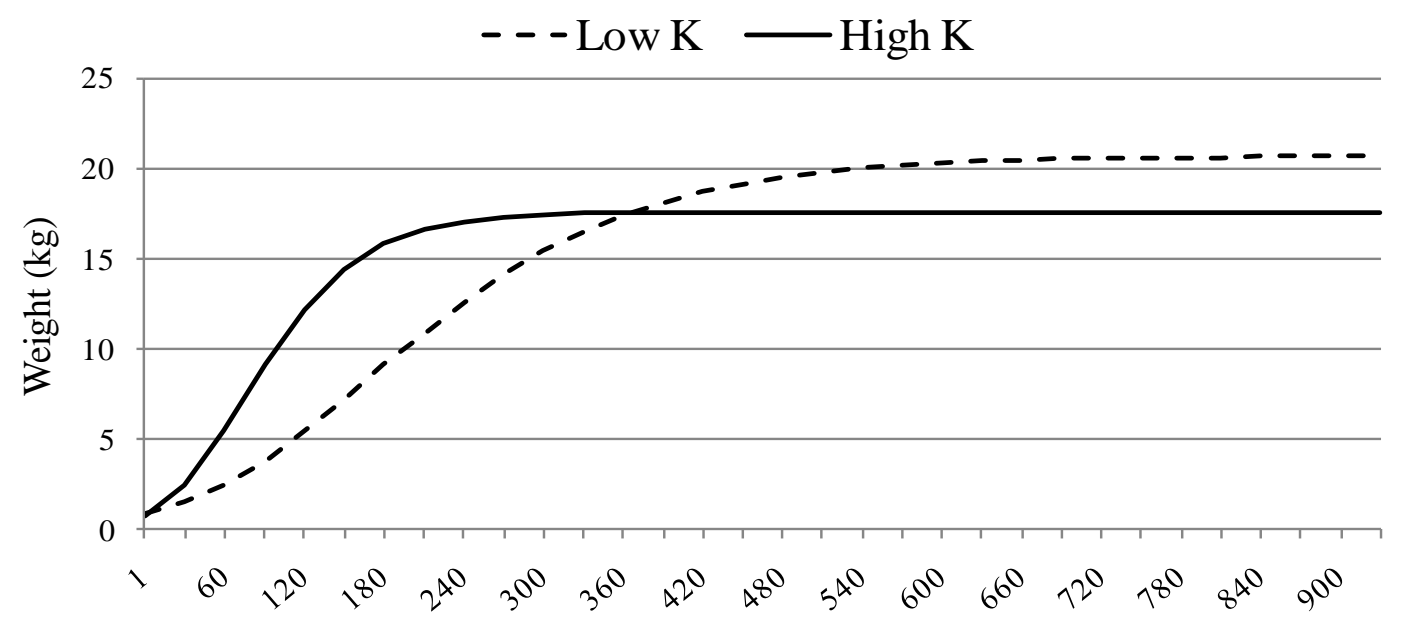

Figure 2. Growth curve estimated with the Brody model for two animals with different growth rates. 
Thus, based on the Asymptotic Rate (Table 1) and viewing the predictive curves (Figure 1), the Brody model provided the best adjustment to describe the growth curve of female collared peccaries. This model should be prioritized for carrying out studies on this species, especially due to it being the simplest model among nonlinear models. However, the other models also provide a satisfactory adjustment for the data and can also be used to describe the weight development of this species.

\section{CONCLUSIONS}

Based on the asymptotic rate adopted in this work, the Brody model is recommended for adjusting the growth curve of the female collared peccaries. Due to the antagonism posed by the parameters with biological interest, the restricted selection indexes could be used more successfully. Nevertheless, studies with groups that are more representative and raised in other conditions are appropriate.

\section{REFERENCES}

BODMER, R.E. Integrating hunting and protected areas in the Amazon. In: Dunstone, N.; Entwistle, A. Future priorities for the conservation of mammals: has the panda had its day? Cambridge: Cambridge University Press, 2000. p.277-290.

BONAUDO, T.; LE PENDU, Y.; FAURE, J.F. et al. The effects ofdeforestation on wildlife along the transamazon highway. Eur. J. Wild. Res., v.51, p.199206, 2005.

BRODY, S. Bioenergetics and Growth. New York: Reinhold Publishing Corp., 1945. 1023p.

DUBOST, G.; DUTERTRE, C.; HENRY, O. Body weight increase in the two peccary species of the genus Tayassu (Tayassuidae, Artiodactyla). Mammalia, v.67, p.55-63, 2003.

FREITAS, A.R. Curvas de crescimento na produção animal. Rev. Bras. Zootec., v.34, p.786-795, 2005.

FUCCIO, H.; CARVALHO, E.F.; VARGAS, G. Perfil da caça e dos caçadores no Estado do Acre, Brasil. $R$. Aportes Andinos, v.6, p.1-18, 2003.
GARNERO, A.D.V.; MARCONDES, C.R.; BEZERRA, L.A.F. et al. Parâmetros genéticos da taxa de maturação e do peso assintótico de fêmeas da raça Nelore. Arq. Bras. Med. Vet. Zootec, v.57, p.652-662, 2005.

LAIRD, A.K. Dynamics of relative growth. Growth, v.29, p.249-263, 1966.

MALHADO, C.H.M.; RAMOS, A.A.; CARNEIRO, P.L.S. et al. Modelos no lineales para describir el crecimiento de bufalinos de la raza Murrah. Arch. Zootec, v.57, p.497-503, 2008.

MAYOR, P.A.; FITA, D.S.; LÓPEZ, B.M. Sostenibilidad en la Amazonia y cría de animales silvestres. Iquitos-Peru: Centro de estudios teológicos de la Amazonía, 2007. 261p.

NELDER, J.A. The fitting of a generalization of the logistic curve. Biometrics, v.17, p.89-110, 1961.

RATKOWSKY, D.A. Handbook of nonlinear regression models. New York and Basel, Marcel Dekker, 1990. 241p.

ROBINSON, J.G.; BODMER, R.E. Towards wildlife management in tropical forests. Jour. Wild. Manag., v.63, p.1-13, 1999.

SANTORO, K.R.; BARBOSA, S.B.P.; SANTOS, E.S. Herdabilidades de Parâmetros de Curvas de Crescimento Não-Lineares em Zebuínos, no Estado de Pernambuco. Rev. Bras. Zootec., v.34, p.2280-2289, 2005.

SANTOS, J.C.C.; MAURO, R.A.; AGUIAR, L.M.S. Cateto - Tayassu tajacu. Fauna e Flora do Cerrado, Campo Grande, Julho 2004. Disponível em: <http://www.cnpgc.embrapa.br/ cateto.html>. Acessado em: 23 Fev. 2012.

SARMENTO, J.L.R.; REZAZZI, A.J.; SOUZA, W.H. et al. Estudo da curva de crescimento de ovinos Santa Inês. Rev. Bras. Zootec., v.35, p.435-442, 2006.

STATISTICAL Analysis Sistem - SAS INSTITUTE. user's guide: statistical, Analysis System Institute, Inc., Cary, NC, 9.1.3. Cary: SAS Institute, 2003.

VON BERTALANFFY, L. Quantitative laws in metabolism and growth. Quarterly Review of Biol., v.32, p.217-231, 1957. 